\title{
Fluid responsiveness predicted by transcutaneous partial pressure of oxygen in critically ill patients
}

\author{
$\mathrm{J} X \mathrm{u}^{1 *}, \mathrm{Y} Y \mathrm{ang}{ }^{2}, \mathrm{H} \mathrm{Qiu}^{2}$ \\ From ESICM LIVES 2015 \\ Berlin, Germany. 3-7 October 2015
}

\section{Objectives}

Our goal was to study the feasibility of predicting fluid responsiveness by transcutaneous partial pressure of oxygen (Ptc02) in the critically ill patients.

\section{Methods}

This was a single centre prospective study conducted in the intensive care unit of a tertiary care teaching hospital. Patients for whom the attending physician decided to perform a fluid challenge or presence of at least one clinical sign of inadequate tissue perfusion in the absence of contraindication for fluid infusion were eligible to participate in the study. Ptc02 was used to continuously record at baseline, during a passive leg raising (PLR), and then during a $250 \mathrm{ml}$ rapid saline infusion in 10 minutes. Fluid responsiveness is defined as a change of stroke volume $\geq 10 \%$ after $250 \mathrm{ml}$ volume infusion.

\section{Results}

Twenty-three patients were included; of whom, 9 responded to volume expansion. In the 9 responders, heart rate, mean arterial pressure, pulse pressure, central venous pressure, cardiac output, stroke volume, Ptc02 all increased significantly $(\mathrm{p}<0.05)$. Fluid responsiveness was predicted by the PLR-induced change of $13.9 \%$ in Ptc02 (area under receiver-operating characteristic curve 0.932) with a sensitivity of $77.8 \%$ and a specificity of $100 \%$.

\section{Conclusions}

In this prospective study, it is suggested that the newly defined parameter, Ptc02 changes during the volume expansion or PLR appears to be a good parameter to predict fluid responsiveness.

${ }^{1}$ Southeast University, Zhongda Hospital, Intensive Care Unit, Nanjing, China Full list of author information is available at the end of the article
Trial RegistrationNCT02083757

Authors' details

${ }^{1}$ Southeast University, Zhongda Hospital, Intensive Care Unit, Nanjing, China. ${ }^{2}$ Southeast University, Zhongda Hospital, Nanjing, China.

Published: 1 October 2015

doi:10.1186/2197-425X-3-S1-A239

Cite this article as: $\mathrm{Xu}$ et al:: Fluid responsiveness predicted by transcutaneous partial pressure of oxygen in critically ill patients. Intensive Care Medicine Experimental 2015 3(Suppl 1):A239.

Submit your manuscript to a SpringerOpen ${ }^{\odot}$ journal and benefit from:

- Convenient online submission

- Rigorous peer review

- Immediate publication on acceptance

- Open access: articles freely available online

- High visibility within the field

- Retaining the copyright to your article

Submit your next manuscript at $\boldsymbol{~ s p r i n g e r o p e n . c o m ~}$

\section{SpringerOpen ${ }^{\circ}$}

(C) 2015 Xu et al.; This is an Open Access article distributed under the terms of the Creative Commons Attribution License (http:// creativecommons.org/licenses/by/4.0), which permits unrestricted use, distribution, and reproduction in any medium, provided the original work is properly cited. 